\title{
Asymptomatic urinary tract infection with multidrug resistant pathogens in retro positive patients on ART
}

\author{
Yadhav K. ${ }^{1}$, Samreen S. $^{2}$ \\ ${ }^{1}$ Dr Kala Yadhav M.L, ${ }^{2}$ Dr Saba Samreen, Postgraduate, both authors are affiliated with Department of \\ Microbiology, Bangalore Medical College and Research Institute, Bangalore, Karnataka, India
}

Address for Correspondence: Dr Saba Samreen, Email id-kysrz_sam5@yahoo.com

\begin{abstract}
Introduction: Asymptomatic urinary tract infection refers to occurrence of bacteria in urine without causing symptoms. UTI is more prevalent among retro positive patients compared to people without HIV. Objectives The study was done to determine prevalence of UTI, common etiologies and antibiotic susceptibility pattern of urinary isolates among HIV seropositive patients attending ART centre for CD4 counts. Materials \& Methods: -A total of 109 patients without any symptoms of UTI were included in the study. AST was done using Kirby Bauer disk diffusion method.CD4 count was done using FACS counter. Results: Out of the 109 cases tested, 55 were males, and 54 cases were females. No growth was seen in $60(55.04 \%)$ samples, insignificant bacteriuria in $9(8.26 \%)$ samples. Significant growth was seen in 40 samples $(36.7 \%)$. Among the 54 females, $44 \%$ had significant growth. Among 55 males, significant growth was seen in $29.1 \%$. The isolated organisms included Escherichia coli - 9(22.5\%), Staphylococcus aureus - 7(17.5\%), Candida albicans - 7(17.5\%). Bacterial isolates showing resistance to three or more categories of antibiotics were considered Multidrug resistant (MDR). Multidrug resistance was seen among 16 bacterial isolates (48.5\%). HIV positive patients with CD4 counts of $<200$ had higher rates of asymptomatic bacteriuria. Conclusion: Screening of HIV seropositive patients with lower CD4 counts for asymptomatic UTI helps in early diagnosis and appropriate, early management of MDR will reduce morbidity.
\end{abstract}

Keywords: Asymptomatic UTI, HIV, CD4 counts, Multidrug resistant

\section{Introduction}

Acquired immunodeficiency syndrome (AIDS) caused by Human immunodeficiency virus (HIV) leads to progressive damage to the immune system, leading to occurrence of various opportunistic infections [1]. Untreated UTI accounts for 7-60\% of opportunistic infections and could be a source for ascending UTI and septicemia in immunocompromised patients [2]. UTI is one of the most common infection causing increased morbidity and hospitalizations in retropositive patients [3] .UTI also accounts for a higher proportion of antibacterial drug usage. There is increasing resistance to the routinely prescribed antibiotics for UTI [4]. These multidrug resistant pathogens are enormously multiplying in HIV patients.

Manuscript received: $05^{\text {th }}$ June 2017 Reviewed: $14^{\text {th }}$ June 2017

Author Corrected: $20^{\text {th }}$ June 2017

Accepted for Publication: 30 $0^{\text {th }}$ June 2017
Asymptomatic urinary tract infection refers to occurrence of bacteria in urine without causing symptoms. UTI is more prevalent among HIV patients compared to people without HIV [5]. This increased risk of bacteriuria correlates with the degree of immunosuppression, as reflected by CD4 count. This study aims to look for the presence of asymptomatic UTI, to identify the common causative organisms causing asymptomatic UTI, to evaluate their AST pattern and also to correlate asymptomatic UTI with gender and CD4 counts in retropositive patients.

\section{Materials and Methods}

Study design: This is a cross sectional comparative study involving asymptomatic HIV patients. Study period: September - December 2016 
Place of study: Department of Microbiology, Bangalore medical college and research institute, Bangalore. Ethical clearance was obtained from Ethical committee.

Inclusion criteria: HIV patients without any symptoms of UTI.

Exclusion criteria: HIV positive patients with age $<18$ yrs, pregnant women, patients having symptoms of UTI.

Sample collection and processing: A total of 109 patients were screened for UTI in a duration of 4 months. The patients were counseled, consent was obtained and a thorough history was taken. The information was kept confidential throughout the study. Results were disclosed only to treating physicians for drug prescription for patients with UTI.

Mid stream urine sample was collected after counseling, from patients in a sterile container under aseptic precautions. Samples were processed within 30mins of collection. Samples were inoculated onto HiMedia Mac Conkey agar, Chocolate agar, Cysteine Lactose Electrolyte Deficient (CLED) agar. Plates were incubated aerobically at $37^{\circ} \mathrm{C}$ for $24 \mathrm{hrs}$ and counts were expressed in colony forming units (cfu) per milliliter (ml). The count of $>10^{5} \mathrm{cfu} / \mathrm{ml}$ was considered significant. Isolates grown were identified using standard biochemical reactions [6].

Antibiotic susceptibility testing was done using Kirby Bauer disk diffusion method. The HiMedia antibiotic discs used for gram negative bacilli were Cotrimoxazole $\quad(23.75 / 1.25 \mathrm{mcg})$, Ciprofloxacin (5mcg), Gentamicicn (10 mcg), Ceftazidime $(30 \mathrm{mcg})$, Nitrofurantoin $(300 \mathrm{mcg})$, Amoxiclav (30mcg), Imipenem(10mcg). Sensitivity of Staphylococcus aureus was tested for Penicillin (10mcg), Azithromycin(15mcg), Cefoxitin (30mcg), Linezolid (30mcg), Cotrimoxazole $(23.75 / 1.25 \mathrm{mcg})$, Clindamycin (2mcg). For Enterococcus disks of Penicillin (10 mcg), Vancomycin (30mcg), Tetracycline (30 mcg), Nitrofurantoin (300mcg), and Ampicillin (10mcg) were used. Results were interpreted as per CLSI 2016 guidelines [7]. Bacterial isolates showing resistance to three or more categories of antibiotics were considered Multidrug resistant. Blood specimens for $\mathrm{CD} 4$ count were collected into EDTA tubes. CD4 count was done using FACS counter.

\section{Results}

Out of the 109 urine samples tested, No growth was seen in 60 cases (55.04\%), insignificant bacteriuria was seen in 9 cases $(8.26 \%)$. Significant growth was seen in 40 cases $(36.7 \%)$. Table $-\mathbf{1}$
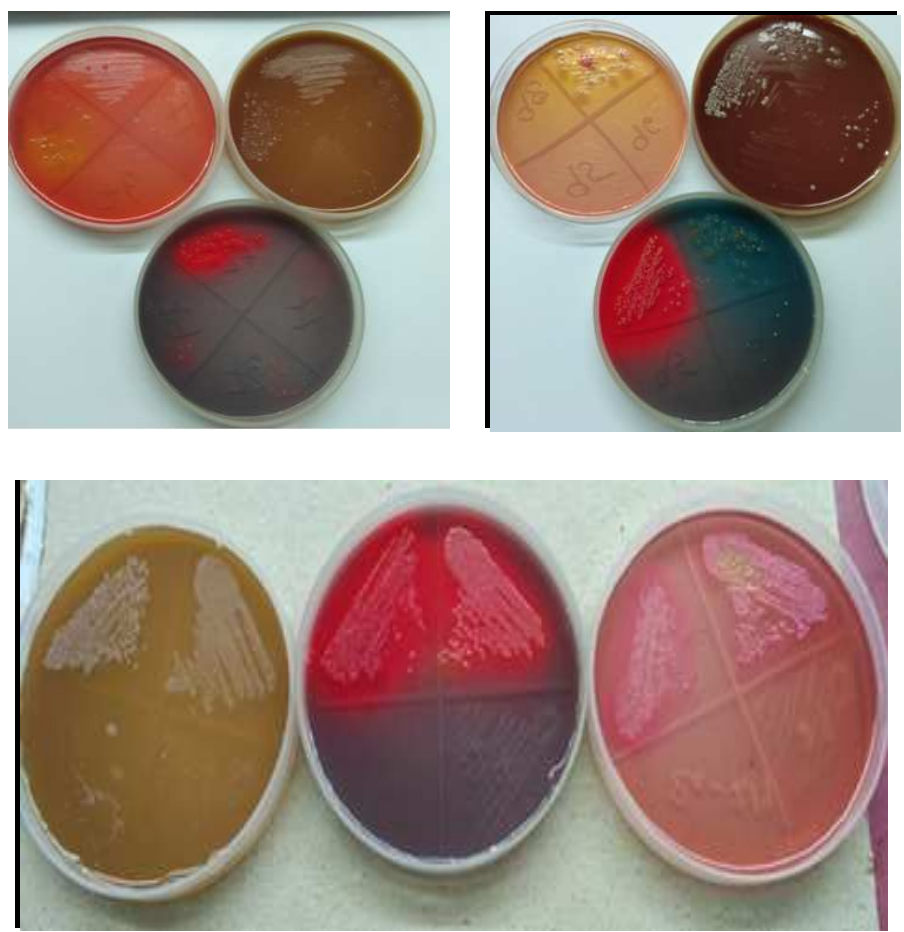

Growth on MacConkey, Chocolate and CLED agar 
Table 1: Prevalence of asymptomatic UTI

\begin{tabular}{|c|c|}
\hline Total screened & $\mathbf{1 0 9}$ \\
\hline No growth & $60(55.04 \%)$ \\
\hline Insignificant bacteriuria & $9(8.26 \%)$ \\
\hline Significant growth & $40(36.7 \%)$ \\
\hline
\end{tabular}

Higher prevalence was seen in females (44.4\%) compared to males $(29.1 \%)$. Out of the 54 females, $44 \%$ had significant growth and among the 55 males, $29.1 \%$ had significant growth. Male to Female ratio in our study was 1:1.53. Table - 2

Table-2: Prevalence of asymptomatic UTI in retropositive males and females

\begin{tabular}{|c|c|c|}
\hline & No. Screened & Growth \\
\hline Male & 55 & $16(29.1 \%)$ \\
\hline Female & 54 & $24(44.4 \%)$ \\
\hline
\end{tabular}

Most common organism isolated was Escherichia coli - 9(22.5\%), followed by Staphylococcus aureus 7(17.5\%), Candida albicans - 7(17.5\%), Gram negative non fermenters - 4(10\%), Klebsiella species - 4(10\%), Enterococcus species - 3(7.5\%), Pseudomonas aeruginosa - 3(7.5\%), Proteus species - 3(7.5\%) Table -3

Table-3: Distribution of organisms isolated

\begin{tabular}{|c|c|c|}
\hline Type of isolate & No. of cases & Percentage \\
\hline E.coli & 9 & $22.5 \%$ \\
\hline C.albicans & 7 & $17.5 \%$ \\
\hline S.aureus & 7 & $17.5 \%$ \\
\hline GNNF & 4 & $10 \%$ \\
\hline Klebsiella & 4 & $10 \%$ \\
\hline Enterococci & 3 & $7.5 \%$ \\
\hline P.aeruginosa & 3 & $7.5 \%$ \\
\hline Proteus spp & 3 & $7.5 \%$ \\
\hline Total cases & $\mathbf{4 0}$ & $\mathbf{3 6 . 7 \%}$ \\
\hline
\end{tabular}

Higher level of resistance was observed to Cotrimoxazole, Ciprofloxacin , Amoxiclav, but most of the isolates were sensitive to Imipenem, Ceftazidime. Most of the E. coli and Klebsiella isolates were sensitive to Gentamicin, Ceftazidime and Imipenem. Most of the Gram negative non fermenters were sensitive to Imipenem. All the Gram negative non fermenters and Pseudomonas aeruginosa isolates were resistant to Cotrimoxazole. All the isolates of Proteus mirabilis were sensitive to Imipenem. 4 out of the 7 Staphylococcus aureus isolates were Methicillin resistant. Table $-\mathbf{4 a}, \mathbf{4 b}, \mathbf{4 c}$

Table-4a: Antibiotic susceptibility pattern for gram negative organisms

\begin{tabular}{|c|c|c|c|c|c|c|c|c|}
\hline ISOLATE & TOTAL & COT & CIP & GEN & CAZ & NIT & AMC & IPM \\
\hline E. coli & 9 & $\begin{array}{c}2 \\
(22.2 \%)\end{array}$ & $2(22.2 \%)$ & $\begin{array}{c}7 \\
(77.7 \%)\end{array}$ & $\begin{array}{c}7 \\
(77.7 \%)\end{array}$ & $\begin{array}{c}6 \\
(66.6 \%)\end{array}$ & $\begin{array}{c}5 \\
(55.5 \%)\end{array}$ & $\begin{array}{c}8 \\
(88.9 \%)\end{array}$ \\
\hline $\begin{array}{c}\text { Klebsiella } \\
\text { pneumoniae }\end{array}$ & 4 & $1(25 \%)$ & $2(50 \%)$ & $3(75 \%)$ & $4(75 \%)$ & $3(75 \%)$ & $2(50 \%)$ & $4(100 \%)$ \\
\hline GNNF & 4 & 0 & $1(25 \%)$ & $2(50 \%)$ & $3(50 \%)$ & $2(25 \%)$ & -- & $3(75 \%)$ \\
\hline $\begin{array}{c}\text { P. } \\
\text { aeruginosa }\end{array}$ & 3 & 0 & $\begin{array}{c}1 \\
(33.3 \%)\end{array}$ & $\begin{array}{c}1 \\
(33.3 \%)\end{array}$ & $\begin{array}{c}2 \\
(66.6 \%)\end{array}$ & -- & -- & $2(75 \%)$ \\
\hline $\begin{array}{c}\text { Proteus } \\
\text { mirabilis }\end{array}$ & 3 & 2 & $1(33.3 \%)$ & $1(33.3 \%)$ & $\begin{array}{c}2 \\
(66.6 \%)\end{array}$ & -- & $1(33.3 \%)$ & $3(100 \%)$ \\
\hline $\begin{array}{c}\text { Total } \\
\text { Sensitive }\end{array}$ & 23 & $26.1 \%$ & $30.4 \%$ & $60.9 \%$ & $78.3 \%$ & $64.7 \%$ & $50 \%$ & $87 \%$ \\
\hline
\end{tabular}


COT $=$ Cotrimoxazole, $\mathrm{CIP}=$ Ciprofloxacin, $\mathrm{GEN}=$ Gentamicin, $\mathrm{CAZ}=$ Ceftazidime, $\mathrm{NIT}=$ Nitrofurantoin, $\mathrm{AMC}=$ Amoxiclav, IPM = Imipenem

Table-4b: Antibiotic susceptibility pattern for Staphylococcus aureus(7 isolates)

\begin{tabular}{|c|c|}
\hline Antibiotic & Sensitive isolates \\
\hline Penicillin & $1(14 \%)$ \\
\hline Cotrimoxazole & $3(42.9 \%)$ \\
\hline Cefoxitin & $4(57 \%)$ \\
\hline Azithromycin & $5(71 \%)$ \\
\hline Linezolid & $6(85.7 \%)$ \\
\hline Clindamycin & $5(71 \%)$ \\
\hline
\end{tabular}

Table-4c: Antibiotic susceptibility pattern for Enterococcus species(3 isolates)

\begin{tabular}{|c|c|}
\hline Antibiotic & Sensitive isolates \\
\hline Penicillin & $1(33 \%)$ \\
\hline Ampicillin & $2(66 \%)$ \\
\hline Vancomycin & $3(100 \%)$ \\
\hline Tetracycline & $2(66 \%)$ \\
\hline Nitrofurantoin & $3(100 \%)$ \\
\hline
\end{tabular}

Multidrug resistance was seen among 16 bacterial isolates (48.5\%). Table $\mathbf{- 5}$

HIV positive patients with CD4 counts of $<200$ had higher rates of asymptomatic bacteriuria. Table - 6

Table-5: Percentage of Multidrug resistant isolates among different bacterial isolates

\begin{tabular}{|c|c|c|}
\hline Type of isolate & No. of isolates & MDR isolates \\
\hline E.coli & 9 & 4 \\
\hline C.albicans & 7 & 4 \\
\hline S.aureus & 7 & 3 \\
\hline GNNF & 4 & 1 \\
\hline Klebsiella & 4 & 1 \\
\hline Enterococci & 3 & 2 \\
\hline P.aeruginosa & 3 & 1 \\
\hline Proteus species & 3 & $\mathbf{1 6}(\mathbf{4 8 . 5 \% )}$ \\
\hline Total cases & $\mathbf{3 3}$ & \\
\hline
\end{tabular}

Table-6: Asymptomatic bacteriuria in patients in relation to CD4 count

\begin{tabular}{|c|c|c|}
\hline CD4 count & Total examined & Growth \\
\hline$<50$ & 7 & $4(57 \%)$ \\
\hline $51-200$ & 28 & $17(60 \%)$ \\
\hline $201-350$ & 23 & $5(22 \%)$ \\
\hline$>350$ & 50 & $14(28 \%)$ \\
\hline
\end{tabular}

\section{Discussion}

Around 40 million people are living with HIV(PLHIV) and about 14,000 people are being added to this pool everyday [8]. Opportunistic infections lead to high morbidity and mortality in people living with HIV/ AIDS patients. Proper diagnosis and management of opportunistic infections will prolong the life of PLHIV and improve their quality of life [2]. 
This study attempts to evaluate the occurrence and prevalence of asymptomatic bacteriuria among HIV positive individuals. The percentage of asymptomatic UTI in HIV patients in our study was $36.7 \%$ which was in concordance to the study by Murugesh K (30\%)[19]. The study by U.C. Essien showed a lower prevalence $(19.3 \%)$ whereas study by Kemajou T.S showed a higher prevalence $(57.3 \%)[9,10]$.

Table -7: Male to female ratio, CD4 counts and organism isolated in other studies

\begin{tabular}{|c|c|c|c|c|}
\hline & $\begin{array}{c}\text { Asymptomatic } \\
\text { UTI }\end{array}$ & Male : Female & CD4 count & Organisms \\
\hline Our study & $36.7 \%$ & $1: 1.53$ & $50-200$ & $\begin{array}{c}\text { E.coli, Staphylococcus aureus, Candida } \\
\text { albicans }\end{array}$ \\
\hline Murugesh T & $30 \%$ & $1: 1.22$ & $50-200$ & $\begin{array}{c}\text { Staphylococcus aureus, Candida spp , } \\
\text { Enterococcus }\end{array}$ \\
\hline U.C. Essien & $19.3 \%$ & $1: 1.52$ & $201-400$ & $\begin{array}{c}\text { E.coli, Klebsiella, } \\
\text { Staphylococcus aureus }\end{array}$ \\
\hline R.Omeregie & $27.28 \%$ & $1: 4.6$ & $>200$ & Staphylococcus aureus Candida, CONS \\
\hline Kemajou .T.S & $57.3 \%$ & $1: 2.01$ & -- & $\begin{array}{c}\text { E.coli, Staphylococcus aureus, P. } \\
\text { aeruginosa }\end{array}$ \\
\hline
\end{tabular}

In our study the male- female ratio was found to be $1: 1.53$. This was similar to the study of Murugesh $\mathrm{K}$ in which the male -female ratio was 1:1.22 [19] and study by U.C Essien in which it was $1: 1.52$. [9] The reason for high prevalence among females may be due to anatomical structure of female urethra (shorter and wider), proximity of female genitalia to anal region. Studies by Inyang-Etoh and Spence MR, have reported a lower prevalence rate in females [11,12].

In our study the most common isolated organism was E. coli (22.5\%) followed by Staphylococcus aureus (17.5\%). This was in concordance with the results of the study by Kemajou[10] .T.S. The study by Michael I.O isolated a higher percentage of E. coli (50\%) but a lower percentage of Staphylococcus aureus (10\%) [13] . The study by Widmer T.A found E. coli to be most common (63\%) followed by Proteus mirabilis (18\%)[14] .

In our study the asymptomatic UTI was more prevalent in patients with CD4 counts of below 200cells $/ \mathrm{mm}^{3}$. Many studies have demonstrated increased susceptibility to UTIs in patients with CD4 count of $<200$ cells $/ \mathrm{mm}^{3}$ $[5,15,16]$. U.C Essien and R .Omeregie showed in their study that prevalence was more in patients with CD4 counts of $>200$ [9,17]. Another study from Bangalore showed that significant bacteriuria occurred in cases with CD4 counts between $300-1000(83.3 \%)$ with a mean of 581[18].

In our study multidrug resistance was seen among 16 bacterial isolates (48.5\%) which lesser than that seen in study by Murugesh K which had MDR of $58.3 \%$ among bacterial isolates [19] ' In a study by Banu A, out of the cases that yielded growth, $91.67 \%$ were resistant to cotrimoxazole which indicates that patients on cotrimoxazole prophylaxis could also be protected from UTI in addition to respiratory infections because of the continuous prophylaxis. However, those patients who were on prophylaxis and developed asymptomatic bacteriuria or UTI should not receive cotrimoxazole as they are most likely to be resistant.[18].

\section{Conclusion}

UTI in HIV patients keeps recurring leading to longer treatment and therefore the treatment should be culture- specific. HIV patients with lower CD4 counts are predisposed to neurological complications like bladder reflexia and hyporeflexia which lead to urinary stasis and infection. There is need to screen retropositive patients with CD4 counts below 200 cells $/ \mathrm{mm}^{3}$ for asymptomatic UTI. Early diagnosis and management of opportunistic infections will reduce morbidity and improve life expectancy of HIV patients.

Funding: Nil, Conflict of interest: None
Permission of IRB: Yes

\section{References}


1. Okolie MN, Eghafona NO, Omeregie R. Anti human immunodeficiency virus agents. J Med Lab Sci 2003; vol-12(1): 1-14

2. Rashmi KS, Ravikumar KL, Jagadeesh, Namitha, Bhagyashree HN, Asymptomatic bacteriuria in HIV/AIDS patients: Occurrence and risks associated with low CD4 counts. JEMDS,2013;2(19):3358-3366

3. Iweriebor $\mathrm{BC}$, Obi $\mathrm{CL}$, Akinyemi $\mathrm{O}$, Uropathogens isolated from HIV infected patients from Limpopo province, South Africa. Afr J Biotech 2012; vol 11, No. 46: 10598-10604

4. Biradar Sk, Srikanth , Doddamani PK, Prevalence and antibiogram of uropathogens in a tertiary care hospital. World Journal of Pharmaceutical Research 2015 vol4 ,issue 1 : 15341543.

5. Schönwald S, Begovac J, Skerk V. Urinary tract infections in HIV disease. Int J Antimicrob Agents. 1999 May;11(3-4):309-11.

6. J G Collee; T J Mackie; J E McCartney , Practical Medical Microbiology ,Churchill livingstone, New York, 14th Edition

7. Clinical and laboratory standards institute guidelines, CLSI 2016

8. Iroha Ifeanyichukwu, Nwakeze Emmanuel, Ejikeugwu Chika, Oji Anthonia, Udu-Ibiam Esther, Afiukwa Ngozi, Ngwu Justina. Frequency and Antibiogram of Uropathogens Isolated from Urine Samples of HIV Infected Patients on Antiretroviral Therapy. American Journal of BioScience. Vol. 1, No. 3, 2013, pp. 50-53. doi: 10.11648/j.ajbio.20130103.11

9. U.C. Essien, C.C. Iheukwumere , G.I. Davou , Z. Sheyin , C.E. Okolie , F.R. Ede and A.I. Ekwempu. : Prevalence and Predictors of Asymptomatic Urinary Tract Infection among HIV Positive Patients in Jos, North Central Nigeria. Int.J.Curr.Microbiol.App.Sci (2015) 4(9): 454-462
10. Kemajou TS, Ajugwo AO, Oshoma CE, Enabulele OI. Antibiotic Resistance of Bacterial Isolates from HIV Positive Patients with Urinary Tract Infection (UTI) in Portharcourt, Nigeria. J AIDS Clin Res 7:594. doi:10.4172/21556113.1000594

11. Inyang -Etoh PC, Udofia GC, Alaribe AAA, Udonwa NE. Asymptomatic bacteriuria in patients on anti retroviral drug therapy in Calabar. $\mathrm{J}$ Med Sci.2009; vol9:270-5

12. Spence MR, Harwell TS, Jones K,. Asymptomatic bacteriuria in women infected with HIV - Int Conf AIDS . 1996;11:283

13. Michael IO, Abel O, Ukoh G. Urinary tract infections in adolescent/young adult Nigerians with acquired immunodeficiency disease in Benin city. J Mol Biol Res 2006;5:55-60

14. Widmer TA, Theron G, Grove D. Prevalence and risks of asymptomatic bacteriuria among HIV positive pregnant women. South Afr J Epidemiol Infect 2010;25:28-32

15. Foxman B. Epidemiology of UTI. Incidence, morbidity and economic costs. Am J Med 2002 july; 113:55-135.

16. Hochreiter WW, Bushman W. Urinary tract infection: a moving target. World J Urol. 1999 Dec;17(6):364-71.

17. Omoregie R, Eghafona NO. Urinary tract infection among asymptomatic HIV patients in Benin City, Nigeria. $\mathrm{Br} \mathrm{J}$ Biomed Sci. 2009;66(4):190-3.

18. Banu A, Jyothi R. Asymptomatic bacteriuria in HIV positive Individuals in a tertiary care hospital. Journal of HIV \& human reproduction. 2013;1(2): $54-57$

19. Murugesh K ,Deepa S, Ravindranath C , Venkatesha D. : Multidrug resistant uropathogen in HIV is a threat to the community. International Journal of scientific study 2014;2(3):38-42.

\section{How to cite this article?}

Asymptomatic urinary tract infection with multidrug resistant pathogens in retro positive patients on ART. Yadhav K., Samreen S.. Int J Med Res Rev 2017;5(06):610-615. doi:10.17511/ijmrr. 2017.i06.10. 